\title{
THE DOUBLE TRACK SYSTEM IN SENTENCING JUVENILE OFFENDERS IN INDONESIA: STRENGTHS AND WEAKNESSES OF THE JUVENILE CRIMINAL JUSTICE SYSTEM ACT 2012
}

\author{
Rusmilawati Windari* \\ Ermania Widjajanti**
}

\begin{abstract}
In light of the various legal responses addressing juvenile offenders, the purpose of this article is to review the formulation of a new sentencing system in Indonesia, regulated by the Juvenile Criminal Justice Act 2012 (JCSA 2012) through the examination of the integration of the equilibrium idea of the double track system in JCJSA 2012. The paper uses normative studies, relevant legislation, as well as the concept of sentencing and the double track system to analyse interrelated issues. All data was analysed in order to gain insight and comprehension of the double track system formulated in a legislation. The results indicate that the sentencing system for juvenile offenders in Indonesia is designed to give priority to divertive, restorative and rehabilitative measures than punitive ones. As a reflection of equilibrium idea, the concept of double track system is still partially reflected in JCJSA 2012. Although the equitable position of sentencing is reflected by categorising various types of sentences and treatment, the functions of both remain unclear and overlap one another. Thus, both sentence and treatment may be executed carelessly and the administration of both may not be geared towards the determined goals. In order to prevent crimes, the effectiveness of the double track system greatly depends on the appropriateness of formulating the equilibrium idea through legislation. The analysis of the double track system is worthy for the policy maker to evaluate the existing legislation and to suggest possibilities for law reform.
\end{abstract}

Keywords: sentencing, double track system, juvenile offender, equilibrium idea

\footnotetext{
* Lecturer, Criminal Law Department, Faculty of Law, Trunojoyo University, Madura, Indonesia. Email: rosemila_21@yahoo.com.

** Lecturer, Criminal Law Department, Faculty of Law, University of Trisakti, Jakarta, Indonesia. Email: erwid_farel@yahoo.com.
} 


\title{
SISTEM LANDASAN BERKEMBAR DALAM PENGHUKUMAN PESALAH JUVENA DI INDONESIA: KEKUATAN DAN KELEMAHAN AKTA SISTEM KEADILAN JENAYAH JUVENA 2012
}

\begin{abstract}
ABSTRAK
Melihatkan kepada pelbagai sambutan perundangan di dalam menangani pesalah juvena, artikel ini bertujuan untuk mengulas formulasi sistem penghukuman yang baru di Indonesia, yang dikawal selia oleh Akta Keadilan Juvena 2012 ('Juvenile Criminal Justice Act 2012 ['JCSA 2012']) dengan mengkaji integrasi idea keseimbangan sistem landasan berkembar yang terkandung didalam JCSJA 2012. Kertas ini menggunakan pengkajian normative, undang-undang relevan, dan juga konsep penghukuman serta sistem landasan berkembar didalam menganalisi isu yang berhubung kait. Segala data telah di analisa bagi mendapatkan wawasan dan kefahaman berkaitan sistem landasan berkembar yang telah diformulasikan didalam sesebuah perundangan. Keputusan yang diperolehi menunjukkan sistem penghukuman pesalah juvena di Indonesia telah di rekabentuk untuk memberi keutamaan terhadap usaha ubahan hala ('divertive'), pemulihan dan penyembuhan berbanding kaedah punitif. Sebagai gambaran kepada keseimbangan idea, konsep sistem landasan berkembara ini sebahagiannya dicerminkan didalam JCJSA 2012. Walaupun kedudukan kesaksamaan penghukuman tergambar dengan mengkategorikan berbagai jenis penghukuman dan perawatan, kedua-dua fungsi ini tetap tidak jelas dan bertindan sesama sendiri. Oleh sedemikian, penghukuman dan perawatan mungkin dilaksanakan secara kurang berhati-hati dan pengurusan kedua-dua pendekatan ini mungkin tidak diselaraskan dengan matlamat yang telah ditetapkan. Untuk membanteras jenayah, keberkesanan sistem landasan berkembar banyak bergantung kepada kesesuaian dalam menformulasikan keseimbangan idea melalui perundangan. Analisis sistem landasan berkembar ini layak untuk diberikan penilaian oleh perundangan sedia ada dan cadangan perlu dibuat bagi menghadapi kemungkinan pembaharuan undang-undang.
\end{abstract}

Kata Kunci: penghukuman, sistem landasan berkembar, pesalah juvena, keseimbangan idea. 


\section{INTRODUCTION}

\section{Protection of Young Offenders}

Children are undeniably the best investment for all communities, from the smallest community as a family, to the largest ones such as a nation. Naturally, children today are the next generation, who significantly have, and indirectly play, a strategic role in achieving sustainable development and quality of human civilisation in the future. The way a society treats children reflects its commitment to the future and human conditions for the coming generation. ${ }^{1}$ Hence, protecting children means protecting life of the family, community and nation in the future. ${ }^{2}$

The protection of children is an effort to provide conditions where every child is able to carry out his/her rights and duties. ${ }^{3}$ It emphasises the fulfillment of children's rights based on their best interests and welfare. ${ }^{4}$ Thus, from that definition, legal protection of children means legal protection for various fundamental rights and freedoms of children, including other interests associated with the welfare of children. $^{5}$

Taking into account the significant relation of children welfare to a country's development, child protection is an inevitable issue which needs to be dealt with immediately by the government. At the international level, it is also an obligation of every country as mandated by the United Nations Convention on the Rights of the Child (hereinafter referred to as 'the UNCRC') in Article 2, section (2), which states as follows:

Each country shall take all appropriate measures to ensure that the child is protected against all forms of discrimination or punishment

$1 \quad$ Javier Perez de Cuellar, former UN Secretary General quoted in D. Victoria and S. Banner Selvi, "A Study on Household Activities of School Going Girl Child and - Its Impact on Their Education and Health Status," in Millennium Development Goals: A Social Science Perspective, ed. J Godwin Prem Singh, Anita Priya Raja, and Florence Shalini (New Delhi: Allied Publishers, 2009), 189.

2 Arief Gosita, Sanksi Alternatif Sebagai Fokus Pembinaan Anak Pidana Saran Pembaharuan Hukum Pidana Indonesia (Jakarta: Pasca Sarjana Fakultas Hukum UI, 2003), 1.

3 Gosita Arif, Masalah Perlindungan Anak (Jakarta: PT. Melton Putra, 1989), 18.

4 Article 3 "Convention on the Rights of the Child," Adopted and Opened for Signature, Ratification and Accession by General Assembly Resolution 44/25 of 20 November 1989 (United Nations Human Rights, 1989).

5 Barda Nawawi Arief, Beberapa Aspek Kebijakan Penegakan Dan Pengembangan Hukum Pidana (Citra Aditya Bakti, 1998), 155. 
on the basis of status, activities, expressed opinions, or beliefs child's parents, guardian or family members. ${ }^{6}$

In this case, the government, as the most responsible body for child protection, must be able to collaborate with all elements in society in order to set up systematic policies, strategies and measures to solve and to guarantee that all children in the country are fully protected.

As clearly prescribed in the UNCRC, every child without exception, irrespective of race, religion, ethnic and status, is entitled to protection. ${ }^{7}$ There is no reason why this should not be extended to children in conflict with the law. Eventhough they have broken the law and consequently may be imposed with particular sentence, they do not deserve to have abusive treatment. All of measures taken by legal enforcers must include protection of their fundamental rights, such as right to protection from abuse and exploitation, right to education, right to nutrition, as well as right to appropriate development. Taking into account that juvenile offenders are more at risk of becoming victims of human rights violations than children in general, both the $\mathrm{UNCRC}^{8}$ and the Children Protection Act No. 23 Year 2002 have strictly ruled that children in conflict with the law are entitled to special protection, and their protection shall be given priority. ${ }^{9}$

\section{Punishing Young Offenders and the Double Track System in Indonesia}

Punishment of young offenders has become an increasing concern for all countries. Various studies have been intensively conducted in many centuries on the appropriate measures that can effectively tackle this. Consideration for children, who are characterised as immature with limited physical, psychological and social abilities necessitates special treatment. In this matter, there are two opposing views on the selection of the best treatment to be provided to them. Under the first view, the treatment shall reflect the implementation of the best interests and welfare of children. This point is in line with the international standards prescribed in several conventions, such as the UNCRC, the United Nations Standard Minimum Rules for the Administration of Juvenile Justice (hereinafter referred to as 'the SMR-JJ'), the United Nations

\footnotetext{
6 "Convention on the Rights of the Child" Article 2, sec.2.

Ibid. Article 2, sec.1.

8 Kimberly Svevo-Cianci and Sonia C Velazquez, "Convention on the Rights of the Child Special Protection Measures: Overview of Implications and Value for Children in the United States," Child Welfare 89, no. 5 (2010): 143.

$9 \quad$ Child Protection Act No. 23, 2002, Article 59.
} 
Standard of the Protection of Juvenile Deprived of Their Liberty, and the United Nations Standard Minimum Rules for Custodial Measures. While under the second view, a crime presumably constitutes a social problem that is considered harmful, resulting in a particular loss, and society deserves protection from any detrimental effects.

Given that a young offender is deemed as doli in capax (incapable of committing a wrong deed) and hence should be treated differently, punishment always becomes a contentious issue. Punishment itself is nested in a wider system commonly known as the sentencing system. In modern criminal law, punishment does not only emphasise on denunciative sanctions, but also advances a more educative treatment for the offender. ${ }^{10}$ In this matter, Karl Christiansen asserts that punishment should be prospective, covering both denunciation and crime prevention for the sake of public welfare. ${ }^{11}$ Furthermore, as a consequence of violation of agreed social norms, John A. Yogis argues that punishment shall include two different types of sanctions, namely sanctions which cover the societal loss, and those applied to punish the crime. ${ }^{12}$ Therefore in respect of both, the adult and juvenile offender, punishment entails the components of denunciation and education.

As part of crime prevention, the effort to stipulate sanctions that are proportionate to the crime is a central issue within penal policy. In order to overcome the negative impact of penal sanctions, the implementation of other educative and rehabilitative sanctions has become an international trend. Theoretically, the idea to apply as well as to equalise penal and treatment sanctions are recognised as the double track system.

In Indonesia, the double track system is not a new idea within the sentencing system. This concept has been adopted very restrictively in the Indonesian Penal Code (commonly known as 'KUHP'), and extensively in other special legislations. Principally, the idea of the double track system emphasises the basics of balance or equality in the imposition of sanctions in criminal law, namely sentence and treatment. Even though a number of legislations have supposedly adopted this idea, it does not mean that the idea of the double track system has been truly construed and comprehensively integrated into the legislations.

In the context of dealing with juvenile offenders, the Juvenile

$10 \quad$ Muladi, Lembaga Pidana Bersyarat (Bandung: Penerbit Alumni, 1997), 151.

11 Karl O Christiansen, "Some Consideration on the Possibility of a Rational Criminal Policy," Resource Material Series, no. 7 (1974).

12 M Sholehuddin, Sistem Sanksi Dalam Hukum Pidana, Ide Dasar Double Track System Dan Implementasinya, PT Raja Grafindo Persada, Jakarta (Jakarta, 2003), 165. 
Justice Act No. 3 Year 1997 is an example of legislation prevailing in Indonesia that adheres to the idea of the double track system. Nevertheless it is opined that such legislation is still lacking. Although this Act was deemed a legal breakthrough by setting forth treatment as an independent sanction similar to penal sanctions, the placement of both sanctions is still unclear because the legislation does not provide any legal reasoning concerning the stipulation of each sanction, whether related to the legal subject, the nature of offence, or the model of sanction imposition. ${ }^{13}$

Since the enactment of the Juvenile Criminal Justice System Act No. 11 Year 2012 (hereinafter referred to as 'the JCJSA of 2012') replaced the Juvenile Justice Act No. 3 Year 1997, the juvenile criminal justice system in Indonesia has undergone some significant changes. Similar to the previous legislation, this new legislation accommodates the double track system into the sentencing system. It also provides more various forms of sanctions that may be imposed by the Juvenile Court Judges on juvenile offenders. Some of those sanctions are new, and not recognised in the series of sanctions provided under the Indonesian Penal Code (KUHP) and other special legislations.

Taking into account the new paradigm as well as sentencing pattern provided in the JCJSA of 2012, this article is mainly geared to examine the formulation of the idea of the double track system in the JCJSA of 2012. Based on the background above, we eventually raise some interrelated issues as follows:

1. How is the sentencing system applied in the Juvenile Criminal Justice System Act No. 11 of 2012?

2. How is the integration of the double track system idea in the sentencing system provided under the JCJSA of 2012?

3. What are strengths and weaknesses of the sentencing model which is adopted under the Juvenile Criminal Justice Act No. 11 Year 2012?

\section{SENTENCING SYSTEM WITHIN THE JUVENILE CRIMINAL JUSTICE SYSTEM ACT NO. 11 OF 2012}

Since the enactment of the Juvenile Criminal Justice System Act No. 11 Year 2012 in July 30, 2012, the juvenile criminal justice system in Indonesia has experienced significant progress. Formulation of sentencing for juvenile offenders, which was initially more oriented

$13 \quad$ Ibid., 192. 
towards offender retaliation, has been shifted to increased focus on offender restoration and reintegration. In terms of handling juvenile offenders, the JCJSA of 2012 minimises the use of custodial measures, but gives priority to divertive, restorative and rehabilitative measures under the principle of the best interest of the children. Additionally, the special character and minimum age of juveniles, are also primarily considered when deciding whether or not to impose a sanction for juvenile offenders.

We cannot discuss the sentencing system without discussing the statutory rules of penal sanctions and punishment. ${ }^{14}$ As contended by Herbert L. Packer, not all punishment is criminal punishment, but criminal punishment must be a punishment. ${ }^{15}$ Packer is of the view that punishment in this matter could be both, penal sanctions and non-penal sanctions (treatment). Furthermore, the sentencing system itself covers all the provisions which regulate how the criminal law is rightly enforced or implemented concretely, so the offender can be sentenced. ${ }^{16}$ Considering the broad scope of the sentencing system, in this study, only some of the following sub systems are analysed within the sentencing system of the JCJSA of 2012, which are as follows:

a. Sentencing goals and guidelines;

b. The minimum age of responsibility;

c. Sentencing pattern, comprising: sorts of sanction, severity level of sanction, mode of sanction imposition.

\section{Sentencing Objectives}

The formulation of sentencing objectives and guidelines occupies a central position in drafting legislation. Naturally, legislation constitutes a purposive system which provides direction and guidance for the judge in sentencing. ${ }^{17}$ In this case, both sentencing objectives and guidelines are intended to play controlling functions, as well as to provide a clear and well directed base of sentencing philosophy, rationality and motivation. ${ }^{18}$

\footnotetext{
14 L. H. C Hulsman, in Bunga Rampai Kebijakan Hukum Pidana (Jakarta: Kencana Prenada Media Group, 2008), 115

15 Herbert Packer, The Limits of the Criminal Sanction (Stanford University Press, 1968), 35 .

16 Barda Nawawi Arief, Bunga Rampai Kebijakan Hukum Pidana: Perkembangan Penyusunan Konsep KUHP Baru (Kencana, 2008), 136.

17 Arief, Bunga Rampai Kebijakan Hukum Pidana: Perkembangan Penyusunan Konsep KUHP Baru.

18 Ibid.
} 
The JCJSA of 2012 however, hardly lays out sentencing objectives set forth in most of legislations in Indonesia. As apparent from the Penal Code (KUHP) or other legislations, sentencing objectives are considered as a prominent part within the legal system in Indonesia. The JCJSA of 2012 is an Indonesian legislation that does not explicitly include certain objectives to achieve in terms of sentencing juvenile offenders.

Although, not specifically regulated in particular provisions, some minimum sentencing objectives within JCJSA of 2012 can still be identified in the general explanatory part of the Act, namely:

a. To embody justice that truly protects the best interest of children in conflict with law (juvenile offenders);

b. To divert children from the trial process, as well as to prevent them from stigmatisation; and

c. To expect children to undergo the reintegration process. Thus, they may return to their social environment in a normal way gradually.

\section{Sentencing Guidelines}

Prior to discussing the sentencing guidelines in the JCJSA of 2012, principally, there are several types of sentencing guidelines: ${ }^{19}$

i. General guidance, which directs judges on matters that should be properly considered in term of sentencing;

ii. Special guidance, which specifically directs judges in selecting or applying certain types of sanction;

iii. Guidance for judges in applying the system of formulation of penal sanctions which is used in formulating the offence.

Similar to sentencing objectives, the JCJSA of 2012 does not explicitly specify that particular provisions are either general or special sentencing guidelines. Nonetheless, some provisions can contextually be figured out as guidelines which are used as some references by a judge in issuing the judgement in juvenile cases. For instance, Article 70 is considered as a general sentencing guideline that regulates several conditions which judges may consider in order to impose a penal sanction or treatment based on justice and humanity. The mentioned conditions above, consists of the following:

$19 \quad$ Ibid., 137. 
a. Criminal offences committed is categorised as petty offences;

b. Personal condition of the juvenile offender; and

c. Circumstances under which the offences were committed and the ensuing consequences;

In addition, another general guideline is also stipulated in Article 71 section (4) which puts forward that the imposition of sentencing shall not violate the dignity of children. Meanwhile, provisions which can be viewed as special sentencing guidelines particularly related to the selection of sanctions, are scattered in several articles from Article 72 to 81 .

\section{The Minimum Age of Juvenile Responsibility}

The minimum age of juvenile responsibility is a debatable topic amongst legal experts. Some experts argue that children who have not attained a certain age at the time of the commission of an offence shall be deemed to act without guilt as they are considered to be incapable of doing wrong, or under English criminal law this is commonly known as "doli incapax". ${ }^{20}$ Consequently, they have no culpability for the wrong they did. On the contrary, some other experts have observed that criminal offences committed by juveniles are getting more grave and serious. Thus, society shall be protected from any losses of crime, even though the perpetrator is a child.

The UN Standard Minimum Rules for the Administration of Juvenile Justice (hereinafter referred to as 'the SMR-JJ') defines Juvenile Offender as a child or young person who is alleged to have committed or has been found to have committed an offense. ${ }^{21}$ Considering each country has a different history and culture, SMR- JJ does not provide child an age limit but only gives general guidelines for each state to formulate a minimum age limit for a child to be culpable, as stated below:

In a legal system recognizing the concept of an age of criminal responsibility for juveniles, such an age level shall not be fixed too low, bearing in mind the facts of emotional, mental an intellectual

20 "The Evolution of Juvenile Justice in Canada" (Canada: Department of Justice), accessed March 12, 2014, http://www.justice.gc.ca/eng/abt-apd/icg-gci/jj2-jm2/ jj2-jm2.pdf.

21 "United Nations Standard Minimum Rules for the Administration of Juvenile Justice ('The Beijing Rules')," A/RES/40/33 29 November 1985 96th Plenary Meeting, accessed October 8, 2015, http://www.un.org/documents/ga/res/40/ a40r033.htm Article 2.2 Sec.C. 
maturity. ${ }^{22}$

In relation to the minimum age of juvenile responsibility, the JCJSA of 2012 tends to be more humane than the Juvenile Justice Act of 1997. In this case, the JCJSA of 2012 has increased the minimum age that attracts criminal responsibility for juveniles. Article 1, point 2 states that child in conflict with the law is a child aged 12 years old, but has not attained 18 years old at the time of the commission of the criminal offence. Furthermore, Article 69 section (2) confirms that only a child above 14 years old can be sentenced.

From both articles above, it can be safely concluded that the range of minimum age of juvenile responsibility is 12 to 18 years old. The range of minimum age is then classified based on the type of sanction that can be inflicted on the juvenile. First, a child aged 12 years old and below 14 years old shall be given treatment (Article 69 section (2)). Second, either sentence or treatment shall be imposed on a juvenile who has attained 14 years old for committing a crime, but has not attained 18 years old. Third, in regard to children under 12 years old and are alleged to have committed a criminal offence, based on Article 21 , the investigator, community supervisor, and professional social workers may take the decision to either return the child to his parents / guardians or send the child to attend educational programs, coaching, and mentoring in government agencies or Social Welfare Institution at central and regional levels for a maximum period 6 (six) months.

\section{Types of Sanction}

Although it was just implemented in July 2014, JCJSA of 2012, the Act has brought some fresh input to the juvenile criminal justice system in Indonesia. The significant paradigm shift from retributive to rehabilitative goals of punishment has resulted in this new legislation being perceived as effective in order to reduce the propensity of the child to commit crimes, as well as to divert the negative impact that imprisonment has on children.

A fundamental change made in the legislation is the determination of sentence and treatment which can be independently imposed on juvenile offenders. The title of chapter $\mathrm{V}$ of this legislation has clearly informed that forms of sanctions imposed on juvenile offenders are sentence and treatment. In Part 2, Article 71 sections (1) and (2), formulates the following types of sentences for juvenile offenders:

$22 \quad$ Ibid. Article 4.1. 
Principal Sentence, consisting of the following:

a. Reprimand

This is the lightest sentence that does not result in restrictions on the freedom of the juvenile offender (Article 72).

b. Conditional sentence (probation)

This suspended sentence may be imposed by the judge and may include imprisonment of not more than two (2) years. The sentence takes effect if the conditions of probation are breached. The general condition of this sentence is that the juvenile will not re-commit any crime during the course of probation. Meanwhile, the special condition on doing or not doing certain things are determined by the court, and shall take into account the young offender's freedom. (Article 73 sections (1), (2), (3), and (4). This sentence may include : Firstly, training outside the institution, such as the necessity to enroll in a coaching program, or counseling, therapy in a mental hospital, or undertaking a rehabilitation program to deal with alcohol, narcotics and psychotropic drugs and other addictive substance abuse (Article 75 section (1)). Secondly, community service, which is intended to educate children by increasing their participation in positive community activities. Thirdly, supervision, by which the daily behaviour of the juvenile at home is supervised by the Public Prosecutor and nurtured by a community supervisor. (Article 77 section (2))

c. Job Training: The sentence is implemented in an institution that undertakes job training which suits the age of juveniles, such as in job training centers, vocational education institutions under supervision of the Ministry of Manpower, Education and Social Services (Article 78 sub section (1))

d. Training in Institutions : The sentence consists of coaching activities which are established by both public and private institutions. The sentence will be imposed if the judge is convinced that a juvenile's circumstances and deeds would not endanger the surrounding community (Article 80 Sub section (1) and (2))

e. Imprisonment: It constitutes the hardest sentence that is only applied as a last resort. When a juvenile offender is imposed 
with imprisonment, he/she will be placed in the Special Juvenile Placement Institution.

Ancillary Sentence, consisting of:

a. Expropriation of benefit derived from the crime; or

b. Fulfillment of customary or traditional obligations

This type of sanction is rarely known within the sentencing system in Indonesia, and constitutes a legal breakthrough that accommodates the diversity of values in Indonesia. The fulfillment of these customary sanctions such as fines or treatment must be fulfilled according to the local customary norms but maintaining the dignity of children and not endangering the children's physical and mental health. ${ }^{23}$

In addition to sentence, the JCJSA of 2012 also recognises a series of treatment. These sanctions focuses on reparative and rehabilitative factors as stipulated in the third part of Article 82 section (1), namely:

a. Returning the juvenile offender to his/her parents/guardians;

b. Surrendering the juvenile offender to particular persons;

c. Treatment in a mental hospital;

d. Treatment in the Institute of Social Welfare Development;

e. Order to attend formal education and/or training that is held by the government or private institution;

f. Revocation of driving license; and

g. Restoring criminal losses.

Both types of sentence and treatment provided in the JCJSA of 2012 have some specific provisions that are rarely found in other special legislation, which can be outlined as follows:

i. Treatment as mentioned above may be proposed by the Public Prosecutor in his indictment, except for a criminal offence committed by the juvenile which carries an imprisonment for a period of not less than 7 (seven) years (Article $82 \mathrm{sub}$ section (3));

ii. The sentencing pattern in the legislation is formulated based on the severity of sanctions, from the lightest, namely reprimand, to the heaviest, namely imprisonment;

iii. Out of the five sentences formulated in the legislation, four sentences are acknowledged to be light, flexible, more

Summarised from the explanation of Article 71 section (2) point b. 
rehabilitative, and re-integrative. While, one sentence is deemed strict, conventional and imperative. Moreover, the fourth sentence mentioned previously are brand new sanctions which are not generally known in the Indonesian Penal Code, or other legislations;

iv. Fine is not regarded as a sanction in the legislation. If a child commits a crime, which is cumulatively imposed by imprisonment and fine, the fine will be replaced with job training (Article 71 section (1));

v. Similar to the previous legislation, the JCJSA of 2012 also strictly prohibits the implementation of the death penalty and life imprisonment for children. Apparently, the legislation has accommodated the principle of subsidiarity in criminal law, in which imprisonment shall be used as a last resort.

\section{The Severity Level of Sanctions}

Unlike the Penal Code and other special legislations, the JCJSA of 2012 does not provide for life imprisonment or the death penalty for juvenile offenders. If the juvenile offender commits a crime with one of those sanctions, the juvenile offender shall be imposed with imprisonment not exceeding 10 years. This provision certainly is in line with the UNCRC which states that the deprivation of liberty shall be used on a juvenile as a measure of last resort, and for the shortest appropriate period of time. Moreover, any kind of capital punishment including the death penalty and life imprisonment is strictly not justifiable to be imposed on juveniles. ${ }^{24}$

With regard to the length of imprisonment for the juvenile offender, the JCJSA of 2012 still maintains a similar provision which prevailed in previous legislation i.e. the Juvenile Justice Act 1997. The basic formula applied is still not exceeding half a maximum term of imprisonment for an adult. Additionally, a significant provision prescribed in the legislation is the prohibition of a special minimum provision on the imposition of imprisonment for juvenile offenders. At a glance, this provision will appear insignificant on the juvenile offender, especially when they commit a crime recognised under the Indonesian Penal Code (KUHP), as the Penal Code only recognises the general minimum provision of sentencing. However, if the prohibition of special minimum provision is applied to other special legislations, which also formulate such special minimum provision in each criminal conduct prescribed inward, the impact will be different and favourably

${ }^{24}$ "Convention on the Rights of the Child" Article $37 \mathrm{sec}$ (a), (b). 
significant to the juvenile offender. The prohibition of applying a special minimum provision reflects the flexibility principle in sentencing which has beneficial effects for juvenile offenders, primarily in order to prevent them from experiencing lengthy term of imprisonment. Indeed, every judge dealing with juvenile cases should apply the spirit of the flexibility principle when passing down sentence. The overall sentencing pattern is reflected in the following table:

\begin{tabular}{|c|c|}
\hline Type of Sanction & Severity Level of Sanction \\
\hline \multicolumn{2}{|l|}{ A. Principal Sentence } \\
\hline 1. Reprimand & $\begin{array}{l}\text { There is no severity level, as long as } \\
\text { it does not exceed the restriction of } \\
\text { freedom of children }\end{array}$ \\
\hline \multicolumn{2}{|l|}{ 2. Conditional Sentence } \\
\hline a. Training outside institution & Overall max: 3 years \\
\hline b. Community Service & Min.3months - Max.120hours \\
\hline c. Supervision & Min. 3 months - Max 2 years \\
\hline 3. Job training & Min.3months - Max. a year \\
\hline 4. Training inside institution & Min.3months - Max. 24 months \\
\hline 5. Imprisonment & $\begin{array}{l}\text { Not exceeding } 1 / 2 \text { of imprisonment term } \\
\text { for adult offender }\end{array}$ \\
\hline \multicolumn{2}{|l|}{ B. Ancillary Sentence } \\
\hline $\begin{array}{l}\text { 6. Benefit Expropriation derived } \\
\text { from the crime }\end{array}$ & $\begin{array}{l}\text { In accordance with the benefit attained } \\
\text { from the crime }\end{array}$ \\
\hline $\begin{array}{l}\text { 7. Fulfilment of customary/tradi- } \\
\text { tion's obligations }\end{array}$ & $\begin{array}{l}\text { In accordance with local custom as long } \\
\text { it still respects children's dignity }\end{array}$ \\
\hline \multicolumn{2}{|l|}{ TREATMENT } \\
\hline 1. Returning to family/foster family & - \\
\hline $\begin{array}{l}\text { 2. Surrendering to particular } \\
\text { persons }\end{array}$ & - \\
\hline 3. Treatment in mental hospital & - \\
\hline
\end{tabular}




\begin{tabular}{|ll|l|}
\hline 4. & $\begin{array}{l}\text { Treatment at the Institute of } \\
\text { Social Welfare Development } \\
\text { (LPKS); }\end{array}$ & \multirow{2}{*}{ Max. a year } \\
\cline { 1 - 2 } 5. & $\begin{array}{l}\text { Obligatory to attend formal edu- } \\
\text { cation and/or training that is held } \\
\text { by the government or private } \\
\text { institution; }\end{array}$ & \\
\cline { 1 - 2 } 6. & $\begin{array}{l}\text { Revocation of driving license } \\
\text { and/or }\end{array}$ & In accordance with the quantity of criminal \\
\cline { 1 - 2 } 7. & $\begin{array}{l}\text { Reparation of criminal impact } \\
\text { (losses) }\end{array}$ & impact (losses) resulted from crime \\
\hline
\end{tabular}

\section{The Mode of Sanction Implementation}

Considering the JCJSA of 2012 does not explicitly include the general sentencing guidelines, and some sanctions prescribed are not recognised under the Penal Code, it will lead to problems in sentencing the juvenile offenders. The JCJSA of 2012 provisions do not describe in detail how judges are to apply those sanctions, and, whether a judge can impose those sanctions mentioned in Article 71 singularly, alternatively, or cumulatively. Within the legislation, what can be considered by the judge when imposing sanctions is merely based on the severity level of crime, personal backgrounds, or the circumstances as the crime committed and the impact emerging afterwards.

In addition, a series of consideration that can be taken into account for judges in sentencing are as follows:

i. If within the substantive law, a certain criminal deed is penalised cumulatively constituting imprisonment and fine, the fine is replaced with job training (Article 71 sub section (3));

ii. The period of sentencing with special conditions is longer than the period of sentencing with general conditions (Article 73 paragraph (5)); This provision is the opposite of Article 29 section (5) of the Juvenile Justice Act of 1997, which stipulated that sentencing period with special conditions must be shorter than that with general conditions;

iii. Child imprisonment is only applied as a last resort (Article 81 section (5)); 
If the crime committed by a juvenile offender is a crime which is imposed with the death penalty or life imprisonment, the sentence that shall be imposed is not exceeding 10 years term of imprisonment (Article 81 section (6));

iii. Juvenile offenders shall be subject to the provision of imprisonment, as long as the related provisions are not contrary to the JCJSA of 2012 (Article 79 section(4));

The treatment cannot be imposed on juvenile offenders committing a crime with an imprisonment term of not less than 7 (seven) years (Article 82 section (3)).

\section{DOUBLE TRACK SYSTEM IN JUVENILE CRIMINAL JUSTICE SYSTEM IN INDONESIA}

\section{Misconception Concerning the Double Track System}

Double track system is essentially a reflection of the equilibrium idea in criminal law, which is oriented on crime and criminal perpetrator (daad-dader Strafrecht). This system admits an equal position of the sentence and treatment in criminal law, in which the concept of equality is expected not only to be applied in the formulation of both sanctions in the sentencing system, but also on how those sanctions equally function as independent measures in preventing crime.

It has been observed that the majority of sentencing policy (notably in other special legislation outside the Penal Code) in Indonesia has referred to the idea of the double track system, but unfortunately there are a few among those legislations which rightly formulate the basic concept of double track system. ${ }^{25}$ Most of the legislations simply apply the treatment as a complementary sentence, by which at this moment, it is presumably considered as the most effective measure to cope with the crime.

The misconception about the double track system, appears in some legislations in Indonesia, for example: ${ }^{26}$

i. The absence of distinctive criteria to define sentence and treatment. Hence, other forms of sanction instead of sentence are viewed as merely formality;

\footnotetext{
25 Sholehuddin, Sistem Sanksi Dalam Hukum Pidana, Ide Dasar Double Track System Dan Implementasinya, 247.

26 Ibid., 163.
} 
ii. The inconsistency in stipulating forms of sanctions within criminal law;

iii. The substance of sentence and treatment presumably overlapped one to another.

Conceptually, both sentence and treatment have characteristics and purposes that are clearly different from one another. ${ }^{27}$ Sentence is a part of general prevention which is more reactive, repressive and pragmatic. The orientation of sentence is criminal deeds which lead to reprisal action and condemnation through indictment. Orientation of treatment of the offender is more rehabilitative, preventive and educative. ${ }^{28}$ As a special prevention with social purpose, the presence of treatment is more geared to systematically assist and educate the offender to adopt good attitude.

In essence, provided that there are several significant distinctive characteristics and purposes between sentence and treatment, the equity position of sentence and treatment in the double track system should be realised by optimising the functions of both correctly and proportionally. ${ }^{29}$ Thus, integrity and balance will be created in achieving the sentence objectives with general and special prevention orientation.

\section{The Nature of Sentence and Treatment on the Basis of the Double Track System}

In criminal law, the conception of designating a deed as a criminal act, and the appropriate punishment for an offender develops gradually with the history and culture in which the law prevailed. In terms of the sentencing theory, a balanced combination of retributive theory implementation that prioritises retaliation, with the utilitarian theory which emphasises treatment of the offender is still considered as the proper solution in imposing proportional sanctions for the offender. In this case, it has been observed that the nature of sanctions is:

A consequence or punishment for violation of accepted norms of social conduct, the purposes which may be of two kinds: those that redress civil injuries (civil sanction), and reviews those that punish

\footnotetext{
$27 \quad$ Ibid.

28 Barda Nawawi Arief and Muladi, "Teori-Teori Dan Kebijakan Hukum Pidana" (Bandung: Penerbit Alumni, 1985), 5.

29 Sholehuddin, Sistem Sanksi Dalam Hukum Pidana, Ide Dasar Double Track System Dan Implementasinya, 207.
} 
crimes (penal sanction). ${ }^{30}$

Criminal sanctions are generally viewed as reactive and repressive sanctions representing the achievement of objectives of revenge, disapproval and retaliation for the criminal act committed (backwardlooking). ${ }^{31}$ Treatment sanctions on the other hand are generally seen as anticipatory, rehabilitative, and educational, to achieve the purpose of treatment for the offender and social restoration from particular circumstances which are dangerous or harmful (forward-looking). ${ }^{32}$ The form of sanction that can be classified as treatment is the conduct that ignores the element of disapproval and the non-physical suffering on the offender.

Relating to this, Barda Nawawi Arief and Sudarto are of the view that sentence imposition should use a humane approach, not just a mere punitive approach. ${ }^{33}$ These sentences shall be in accordance with the values of civilised humanity and is also able to raise awareness of the offender on the values of social life and humanity. Sudarto also stated that discussing sentence shall mean discussing why people commit crimes. Hence, human values have a place within penal reform and should not be waived. ${ }^{34}$

Although the effectiveness and advantages of penal sanctions (sentence) in preventing crimes in society are increasingly unconvincing, its existence is still necessarily required. Some legal experts believe that removing the penal sanctions from the sentencing system is rather impossible. As a crime prevention measure, the penal sanction has opposing sides, by which the effectiveness and advantages actually depend on how the legal enforcer operates it. Herbert L. Packer contends that penal sanctions can play two different functions. It can be the prime guarantor if it is applied humanly and impartially. On the contrary, it can be a primary threat if it is applied coercively and indiscriminately. ${ }^{35}$

In line with Packer, Barda Nawawi Arief is of the view that the use of penal sanctions as an effort to overcome the excesses of crime is only justified if there is a worthy necessity for society. Moreover, the limits

\footnotetext{
$30 \quad$ Ibid., 165 .

31 Michael Cavadino and James Dignan, The Penal System: An Introduction (London: Sage Publications, 1992), 32-33.

32 Ibid., 32.

33 Arief, Bunga Rampai Kebijakan Hukum Pidana: Perkembangan Penyusunan Konsep KUHP Baru, 38.

34 Hukum Sudarto, Hukum Pidana Dan Perkembangan Masyarakat (Bandung: Sinar Baru, 1983), 102.

35 Packer, The Limits of the Criminal Sanction, 366.
} 
of the penal sanctions should be determined based on the interests of society itself and for the sake of the values which realise it. ${ }^{36}$

In the context of the juvenile criminal justice system, the selection and imposition of the appropriate sanctions toward the juvenile offender become a more complex problem compared to sanctions for adults. In association with the idea of the double track system, Horst Schroder emphasises on the obvious different functions of sentencing, and the types and severity level of sanctions. ${ }^{37}$ Therefore, the effort to distinguish between sentence and treatment in juvenile criminal law is not an easy matter. ${ }^{38}$

The difficulty in distinguishing substances of sentence and treatment in juvenile sentencing system is due to, on the one hand, the offender's status as a child, which requires special efforts taking into account the child's current personal integrity and well-being in the future. Conversely, on the other hand, the damage, injury or misery caused by their criminal act is getting more varied and improved in terms of quality and quantity. Even lately, it is seldom that children of a certain age, notably those whose age are closely approaching adulthood, are capable of being violent as adult offenders are.

Internationally, the paradigm of "do not punish but educate" 39 has become the spirit to develop the juvenile justice system which prioritises the interest of children. The handling of a juvenile offender by implementing punitive punishment is no longer deemed effective and results in more disadvantages not only to children themselves but also the future of a country. In terms of sanction imposition, Arief Gosita conveyed his view that sentencing should be undertaken for the sake of truth, justice and offender's well-being. ${ }^{40}$ Moreover for the juvenile offender, the penal sanction should cover perspective of the truth, justice and welfare of the child. Thus, sentencing for juvenile offenders should not aim at retaliation, but education for their welfare in the future.

Referring to international standards, sanctions that are educative

\footnotetext{
36 Arief, Bunga Rampai Kebijakan Hukum Pidana: Perkembangan Penyusunan Konsep KUHP Baru, 36.

37 Sholehuddin, Sistem Sanksi Dalam Hukum Pidana, Ide Dasar Double Track System Dan Implementasinya, 207

38 Gosita, Sanksi Alternatif Sebagai Fokus Pembinaan Anak Pidana Saran Pembaharuan Hukum Pidana Indonesia, 19.Gosita, Sanksi Alternatif Sebagai Fokus Pembinaan Anak Pidana Saran Pembaharuan Hukum Pidana Indonesia, 19

39 Ido Weijers and Tom Liefard, "Yougsters," in Dutch Prisons, ed. Martina Maria Boone and Martin Moerings (The Netherlands: BJV Legal Publisher, 2007), 127.

40 Gosita, Sanksi Alternatif Sebagai Fokus Pembinaan Anak Pidana Saran Pembaharuan Hukum Pidana Indonesia, 193.
} 
and rehabilitative for juveniles have fundamentally been in line with what is mandated by the core principles prescribed under the United Nations Convention on the Rights of the Child (UNCRC), and Article 5.1 SMR-JJ.According to both international conventions, the imposition of sanctions on juveniles should not only focus on the criminal act as well as the consequences, but also on some considerations attached to the children in general, namely the characteristics of a child as a human with limited physical, psychological, and social abilities, the best interests of a child and the child's future welfare.

However from the sentencing objective perspective, the stipulation of a sentence which merely emphasises on the element of education (treatment) for the offender, and that ignores the element of denunciation, is against the basic concept of each sanction. As already mentioned previously, both sentence and treatment basically have distinctive purposes and basic ideas.

If the purpose is public protection from harmful conduct of the offender, the sentence imposition is applicable. On the contrary, if the purpose is to coach or to rehabilitate the offender, treatment sanction is necessarily imposed. Hence, without leaving the aspects of rehabilitation and education of the offender, it is suggested that stipulation of proportional sanctions for juveniles should be applied within borderlines of the basic idea of each sanction, and the final goal of sentencing is to be achieved by the related legislations.

If this point is ignored, the implementation of sanctions in the related legislations will be far from effective, owing to the vagueness of the term, and overlapping substance amongst forms of sanction are not inevitably avoidable. ${ }^{41}$

\section{Implementation of the Double Track System in the Juvenile Criminal Justice Act No. 11 Year 2012}

In addition to including treatment that is much more different from the previous legislation, the JCJSA of 2012 has also adopted the idea of the double track system within its sentencing system. The idea of the double track system is clearly reflected in the title of Chapter V, namely Sentence and Treatment. Furthermore, the nature of the double track system is expressively prescribed in Article 69 section (1), which states that a juvenile court judge may only impose sentence or treatment as stipulated in the JCJSA of 2012.

Based on the formulation of the article above, it indicates that the

${ }^{41}$ Sholehuddin, Sistem Sanksi Dalam Hukum Pidana, Ide Dasar Double Track System Dan Implementasinya, 207. 
JCJSA of 2012 admits the equality function of sentence and treatment. In this case, treatment is no longer viewed as a complementary sanction, but an independent one, whose existence equals to sentence in order to handle crime. As a result, the equality concept in that article then brings the juridical consequences on judges' independency in selecting an appropriate sanction for juvenile offender by considering of justice and humanitarian aspects.

In addition to the function of equity of sanction, another fascinating provision of the double track system in the JCJSA Of 2012 is that various forms of both sentence and treatment sanctions are provided and may be chosen by the judge in terms of addressing the criminal act committed by a juvenile offender. The forms of sanction mentioned earlier, are as follows:

Table 2 : Forms of Sentence and Treatment Under the JCJSA of 2012

\begin{tabular}{|c|l|l|}
\hline No. & \multicolumn{1}{|c|}{ Orientation } & \multicolumn{1}{c|}{ Criteria } \\
\hline \multirow{2}{*}{1.} & \multirow{2}{*}{ Criminal Act } & The light quality of criminal act committed (Article 70) \\
\cline { 3 - 4 } & $\begin{array}{l}\text { Circumstances when the criminal act committed, or the } \\
\text { possible consequences will occur afterward (Article 70) }\end{array}$ \\
\hline 2. & $\begin{array}{l}\text { Offender } \\
\text { Personality }\end{array}$ & $\begin{array}{l}\text { The minimum age of offender to be administered sen- } \\
\text { tence shall not be less than 14 years old (Article 69 sec- } \\
\text { tion (2)) }\end{array}$ \\
\cline { 3 - 4 } & & Personal background of Juvenile Offender (Article 70) \\
\hline
\end{tabular}

Based on the table above, the majority of the sanctions substance provided in the JCJSA of 2012 are educative and rehabilitative. From several sanctions available, only imprisonment is punitive, and applied specifically to cases of violence and public disturbance. Another interesting point of this legislation is that a fine is no longer included as a sentence that can be imposed on a juvenile offender. As stated earlier, if a juvenile offender commits a crime punishable with imprisonment and fine, the fine can be replaced with job training.

Pertaining to sentencing guidelines, the JCJSA of 2012 has also provided the equilibrium criteria that can be used as a basis of consideration for juvenile court judges in imposing appropriate sanctions for juvenile offenders. The intended criteria represent the idea of sanction equity, which are oriented to both, the criminal act and the personality of the offender. In criminal law science, this idea is also known as mono dualistic, which sets out community and individual protection aspects in equal position. 
Within the JCJSA of 2012, the community protection aspect is reflected in the provision of maximum scale of sentencing formulated in each criminal act provision. While individual protection is reflected in the provisions relating to prohibition of the imposition of a special minimum term of imprisonment against juveniles, consideration of a juvenile's personal condition as well as their future are to be accounted by the judge in determining the type of sentence to be imposed on a juvenile offender. The criteria are set out in Article 69 section (2) and Article 70, which are as follows:

Table 3: Criteria of the Sentence Imposition on Juvenile Offender

\begin{tabular}{|c|c|c|}
\hline No. & Orientation & Criteria \\
\hline \multirow[b]{2}{*}{1.} & \multirow[b]{2}{*}{ Criminal Act } & The light quality of criminal act committed (Article 70) \\
\hline & & $\begin{array}{l}\text { Circumstances when the criminal act committed, or the } \\
\text { possible consequences will occur afterward (Article 70) }\end{array}$ \\
\hline \multirow[t]{2}{*}{2.} & \multirow[t]{2}{*}{$\begin{array}{l}\text { Offender } \\
\text { Personality }\end{array}$} & $\begin{array}{l}\text { The minimum age of offender to be administered } \\
\text { sentence shall not be less than } 14 \text { years old (Article } 69 \\
\text { section (2)) }\end{array}$ \\
\hline & & Personal background of Juvenile Offender (Article 70) \\
\hline
\end{tabular}

Based on the table above, the criteria provided in Article 70 are negatively formulated and implies the concept of limited judicial pardon, indicating that the juvenile court judge may act leniently by not imposing sentence or just administering treatment on the juvenile offender meeting the criteria through consideration of justice and humanity

Although the JCJSA of 2012 equally considers treatment and this can be independently applied by the judge, it does not automatically mean that treatment can be implemented carelessly. In this matter, the JCJSA of 2012 provides guidance on how treatment can be carried out based on the age of the juvenile offender which are as follows:

i. It is obligatory for the juvenile court judges to impose treatment on juvenile offenders aged 12 to 14 years old;

ii. For the sake of justice, humanity and their best interest, the treatment may be imposed on juvenile offenders aged 1418 years old, as long as they have met the criteria set out in Article 70;

iii. Notably for children not exceeding 12 years old who commit 
criminal acts, their cases will not proceed to the higher stages (prosecution and trial stages), and they may be imposed a treatment prescribed in Article 21, namely: returning to parents or guardian, and involving them in education programmes, including mentoring and coaching that will be carried out by selected government agencies or social welfare institutions.

\section{THE STRENGTHS AND WEAKNESSES OF FORMULATION OF THE DOUBLE TRACK SYSTEM UNDER THE JUVENILE CRIMINAL JUSTICE ACT NO. 11 YEAR 2012}

\section{The Strengths}

Based on the previous analysis, it can be deduced that the formulation of the double track system idea in the JCJSA of 2012 has several positive points that addresses the disadvantages of the previous legislation, which are as follows:

a. Sentence and treatment have been independently formulated and administered and freedom is given to the juvenile court judges to selectively impose either sentence or treatment on juvenile offenders. It clearly indicates that the JCJSA of 2012 has comprehended the basic concept of the double track system within its penal policy, which emphasises on the function of equality of sentence and treatment in order to address juvenile criminal cases;

b. Forms of sentence and treatment provided in the JCJSA of 2012 are more varied and prioritises anticipative, educative and rehabilitative sanctions, bordering on the child's best interest, rather than punitive;

c. The sentencing system adopted in the JCJSA of 2012 has accomodated the equilibrium idea of sanction, which is oriented to the criminal act and the personality of the offender. In association with the selection of the appropriate sanction for a juvenile offender, De Vries stated that the choice between a penalty and a measure (treatment) also has to be decided based on assessment of the desired effect on the child and not on the basis of his guilt or responsibility; ${ }^{42}$

42 Weijers and Liefard, "Yougsters," 129. 
d. In addition, the sentencing policy of the JCJSA of 2012 has also applied the monodualistic idea, the limited judicial pardon idea, the idea of penal modification and the idea of advancing justice rather than legal certainty;

e. The formulation of the double track system in the JCJSA of 2012 is completed with juridical criteria (guidelines) that enable the juvenile court judge to prevent juvenile offenders from punitive sanctions, to be substituted with treatment imposition.

\section{Weaknesses}

Inspite of improvements and advantages, the formulation of the double track system within the JCJSA of 2012 also has a series of interrelated weaknesses, which are as follows:

a. It is found that the legislation does not explicitly prescribe the sentencing objective that is intended. It also does not juridically define terms of sentence and treatment. Consequently, it leads to the vagueness of sanction substance. Eventually, the imposition of such sanction will not be relevant to the targeted legal interest;

b. Overlapping functions occur between sentence and treatment. On this point, most of the sentences provided in the JCJSA of 2012 tend to contain similar substance to several forms of treatment. For instance, conditional sentence and ancillary sentence in which the substance of those sentences essentially constitute the substance of treatment whereas theoretically, both sentence and treatment should have had totally different concept and purposes;

c. The JCJSA of 2012 has not furnished special guidelines for the judges in selecting an appropriate treatment to be imposed on juvenile offenders in accordance with the personal conditions and the juvenile capacity of liability. The criteria provided in the legislation is only based on the age measurement;

d. Forms of sentence and treatment provided in the JCJSA of 
2012 are relatively new, and those are not recognised under the Indonesian Penal Code as well as other legislations. Therefore, where the legislation does not provide any adequate legal explanation and specific guidelines in operating those sanctions, it will be difficult to implement the sanctions.

\section{CONCLUSION}

The Juvenile Criminal Justice System Act No. 11 Year 2012 (the JCJSA 2012) is a legal breakthrough in addressing juvenile criminal cases, particularly in the context of the sentencing system and the basic idea of punishing juvenile offenders. In terms of the sentencing system, JCJSA 2012 has not explicitly provided legal objectives of punishing juvenile offenders, and has not specified some provisions as either being general or special sentencing guidelines. Nevertheless, some provisions relating to minimum age of juvenile responsibility and sentencing pattern seem to be a prominent legal reform. The JCJSA 2012 prescribes that the juvenile age as they commit a crime may determine different legal actions. Generally, juvenile offenders can be criminally charged when they attain 12 to 18 years of age. Only juvenile offenders whose ages are above 14 to 18 years old can be imposed with penal sanctions, and when their ages are 12 to less than 14 years old, they only undergo one or some type of treatment. With regard to sentencing pattern, the JCJSA 2012 provides lighter, more various and flexible penal sanctions than did a previous regulation. Besides imprisonment, the JCJSA 2012 also applies some non-punitive sanctions such as reprimand, job training, fulfilment tradition obligation and restoration of criminal losses. The imposition of a fine, the death penalty and life imprisonment are not recognised anymore. The JCJSA 2012 also strictly prohibits the imposition of special minimum length of imprisonment, allows imprisonment just as a last resort and provides guidelines for judges in terms of imposing proper sentence for juvenile offenders, such as severity of criminal deeds and personal backgrounds of juvenile offenders.

In terms of the basic idea of sentencing, the JCJSA does not only focus on divertive and restorative measures, but also emphasises the equilibrium idea, which is commonly known as the double track system. The idea is reflected in the integration of the equality function in formulating sentence and treatment. The JCJSA 2012 provides various forms of sentence and treatment, in which the function of both is viewed as equally important and independent. Another reflection 
of the equilibrium idea appears on orientation of sanction which is geared to both, the community protection aspect, such as stipulation of a maximum scale of sentencing, and the individual protection aspect, such as prohibition of imposing a special minimum scale of sentencing to juvenile offenders.

Eventhough the JCJSA 2012 evidently revolutionises the development of the juvenile justice system in Indonesia, unfortunately the implementation of the double track system idea in the JCJSA 2012 still has several weaknesses which need to be improved, for instance the absence of sentencing objectives, the overlapping substance of sentence and treatment, and the vagueness in the meaning of sanctions

In order for the double track system to be more effective in addressing juvenile criminal cases, the amendment of the Juvenile Criminal Justice Act of 2012 becomes indispensable. Firstly, the legislator should consider stipulating the legal objectives of punishing juvenile offenders reflecting the equilibrium idea, such as the idea to equalise the interests of community and the individual (offender) protection. Subsequently, legislators should re-evaluate and adjust all sentencing provisions such as types, severity level, and imposition mode of sanctions, with the prescribed sentencing objectives. Secondly, it is also highly recommended to provide clear legal definitions for each sanction in the JCJSA of 2012, so that the tendency for overlapping provisions may be avoided. Thirdly, taking into account that the JCJSA of 2012 provides several sanctions which are not recognised under the Penal Code of Indonesia, and as a special legislation, the JCJSA of 2012 must include clear sentencing guidelines which can become parameters for judges in properly dealing with juvenile criminal cases. 